\title{
Effect of Aloe vera on nitric oxide production by macrophages during inflammation
}

\author{
\#D. Sarkar, ${ }^{\star \star}$ A. Dutta, *M. Das, ${ }^{\star} K$. Sarkar, ${ }^{\star \star} C$. Mandal, *M. Chatterjee
}

\begin{abstract}
$\sqrt{2}$
*Department of Pharmacology, Dr. BC Roy Postgraduate Institute of Basic Medical Sciences, I.P.G.M.E.R., 244B Acharya JC Bose Road, Kolkata- 700020 and

**Department of Immunobiology, Indian Institute of Chemical Biology, Kolkata.

\#Present address: Depatment of Zoology, Dinabandhu Mahavidyalaya, Bongaon, North 24 Parganas, West Bengal.

Received: 15.3.2005

Revised: 4.7.2005

Accepted: 5.7.2005

Correspondence to: Mitali Chatterjee E-mail: ilatim@vsnl.net
\end{abstract}

\section{Introduction}

Inflammation is generally considered as an essentially protective response to tissue injury caused by noxious physical, chemical or microbiological stimulus. It is a complex process involving various mediators, such as prostaglandins, leukotrienes and platelet activating factor. ${ }^{[1]}$ The major macrophage derived inflammatory mediators such as proinflammatory cytokines, tumour necrosis factor- $\alpha$ (TNF- $\alpha$ ) and the reactive free radical nitric oxide (NO) synthesized by inducible NO synthase (iNOS), contribute to the development of inflammatory diseases. ${ }^{|2|}$ Thus, inhibition of the excessive production of TNF- $\alpha$ and/or NO could be employed as criteria to evaluate potential antiinflammatory compounds. The current management of inflammatory diseases is limited to the use of antiinflammatory drugs whose chronic administration is associated with several adverse effects. Plant-derived products are slowly emerging as a viable alternative because they are cheap, abundantly available and relatively less toxic.

The genus Aloe belongs to the Asphodelaceae family, Alooideae subfamily, and comprises about 420 species of succulent plants. They are indigenous to southern and eastern
Africa and Madagascar but have been introduced in other tropical countries, the Mediterranean area and the West Indies. ${ }^{[3]}$ Aloe has been used as a folk medicine for 3000 years and in the last decade Aloe vera is being extensively used in health drinks, topical creams, toiletries and cosmetics. ${ }^{[4]}$ From the leaves of Aloe plants, three types of commercial products are obtained namely, the dried exudate, excreted from the aloin cells present in the zone of the vascular bundle, the gel, a mucilaginous juice present in the centre of the leaf and the oil, extracted by organic solvents. ${ }^{[3]}$ The dried exudate is used as a bitter in alcoholic beverages while the oil, comprising the fatty fraction of the leaf is used primarily in the cosmetic industry as a pigment carrier and soothing agent. Studies have shown that the gel component has antiinflammatory activity ${ }^{[5]}$ that is mediated through antibradykinin ${ }^{[6]}$ activity and inhibition of prostaglandin production. ${ }^{[7]}$ However, no studies have been undertaken with regard to the antiinflammatory activity of the leaf exudate. Accordingly, in this study, we have evaluated the antiinflammatory potential of Aloe vera leaf exudate as also demonstrated that this antiinflammatory activity is mediated partly via reduction of nitric oxide production in macrophages. 


\section{Materials and Methods}

\section{Animals}

Male albino Wistar rats (100-120 g) and Swiss albino mice (av. wt. 25-30 g) were used. All animals were housed under standard conditions of temperature $\left(25 \pm 5^{\circ} \mathrm{C}\right)$. A 12 -h light/ dark cycle was maintained and the animals were provided with standard pellet diet and water ad libitum. They were acclimatized for one week and then subdivided for different experimental schedules. The experiments were carried out after getting approval from the Institutional Animal Ethics Committee.

\section{Chemicals and drugs}

Napthyl ethylene diamine dihydrochloride [NED (Loba Chemie)], sulphanilamide, zymosan, phenazine methosulphate [PMS (SRL)], MTS: \{3-(4, 5 dimethylthiazol-2-yl)-5(carboxymethoxyphenyl $\}$-2-(4- sulphophenyl)-2H tetrazolium (Promega), Indomethacin (Inmecin 25, E.M. Pharmaceuticals Pvt. Ltd., India), dexamethasone (Dexona, Cadila Healthcare Ltd., India), Complete Freund's Adjuvant, Carrageenan and dextran were obtained from Sigma, MO, USA.

\section{Preparation of plant extract}

Fresh succulent leaves of Aloe vera were collected, the inner gel component removed and the leafy exudate homogenized in an electric grinder. This was subsequently lyophilized and stored at $4^{\circ} \mathrm{C}$. It was solubilized in dimethylsulfoxide (DMSO, $50 \mathrm{mg} / \mathrm{ml}$ ), labelled as AVL and used for all experiments.

\section{Tests for acute inflammation}

\section{Carrageenan or dextran-induced edema}

Animals were divided into four groups $(n=6)$. In all the groups, acute inflammation was induced by injection of either $0.1 \mathrm{ml}$ of freshly prepared carrageenan $(1.0 \%)$ in $0.9 \% \mathrm{w} / \mathrm{v}$ $\mathrm{NaCl}$ solution ${ }^{[8]}$ or $0.1 \mathrm{ml}$ of dextran $(2 \%)$ in $0.9 \% \mathrm{w} / \mathrm{v} \mathrm{NaCl}$ solution ${ }^{[9]}$ into the subplantar region of the hind paw of rats. AVL in different doses (0- $25 \mathrm{mg} / \mathrm{kg}$, b.w.) and indomethacin (2.5, 5 and $10 \mathrm{mg} / \mathrm{kg}$, b.w., as a standard reference) were orally administered one hour before injection of the phlogistic agent. The paw volumes were measured plethysmographically (using water) once prior to administration of the phlogistic agent and thereafter at hourly intervals for $3 \mathrm{~h}$. The percentage of inhibition was calculated as follows ${ }^{[10]}$

$$
\stackrel{\mathrm{E}_{\mathrm{c}}-\mathrm{E}_{\mathrm{t}}}{ } \times 100
$$

$\mathrm{E}_{\mathrm{c}}$

where $E_{c}$ is the edema volume of the control group and $E_{t}$ is the edema volume of the treated group.

\section{Test of chronic inflammation}

Freund's complete adjuvant induced arthritic model

Rats were divided into three groups $(n=6)$. Experimental arthritis was induced according to the method of Newbould $e t$ al. ${ }^{[11]}$ Briefly, $0.1 \mathrm{ml}$ of Freund's complete adjuvant was injected intradermally into the plantar aspect of the hind paw of each animal. Animals were administered AVL $(25 \mathrm{mg} / \mathrm{kg}$, b.w., orally) and dexamethasone $(0.1 \mathrm{mg} / \mathrm{kg}$, b.w., orally, as a standard reference) for the initial 13 days. The degree of inflammation was measured plethysmographically; accordingly, edema formation and the percentage of inhibition was calculated as described above on days 1, 3, 5, 9, 13 and 21 and the primary and the secondary lesions were measured.
Primary lesions refer to the edema formation in the injected hind paw that peaks 3-5 days after injection of the phlogistic agent and is measured on day 5 by calculating the percent inhibition of the edema volume of the injected paw using the formula described above. Secondary lesions are immunologically mediated changes characterized by inflammation of the non-injected sites (hindleg, forepaw, ears nose and tail) decrease in weight and occur after a delay of 11-12 days. Accordingly, secondary lesions were evaluated by calculating the percent inhibition of paw volume of the noninjected right paw over control on day 21 and using an arthritic index as the sum of scores according to the method of Schorlemmer. ${ }^{12]}$

\section{Lesion site Nature of lesion}

Ear a. Absence of nodules and redness. 0

$\begin{array}{ll}\text { b. Presence of nodules and redness. } & 1 \\ \text { a. No swelling of connective tissue. } & 0\end{array}$

b. Intense swelling of connective tissue. 1

Tail a. Absence of nodules.

b. Presence of nodules.

Forepaw a. Absence of inflammation.

b. Inflammation of at least one joint.

Hind paw a. Absence of inflammation.

b. Slight inflammation.

c. Moderate inflammation.

d. Marked inflammation.

\section{Preparation of mouse peritoneal macrophages}

To elicit activated peritoneal macrophages, mice were injected i.p. with starch [2\% in phosphate buffered saline (PBS), $0.02 \mathrm{M}, \mathrm{pH} 7.2,2 \mathrm{ml} / \mathrm{mice}$. After three days, the peritoneal cells comprising principally macrophages were lavaged with sterile PBS $(10 \mathrm{ml})$. The exudate was centrifuged at $4000 \mathrm{rpm}$ for 10 min and the resultant cell pellet washed in PBS and finally resuspended in complete RPMI-1640 phenol red free medium supplemented with $10 \%$ fetal calf serum (FCS) ${ }^{\cdot 13 \mid}$ Macrophage viability (>95\%) was confirmed by the Trypan blue dye exclusion technique.

\section{Measurement of nitric oxide (NO) production in macrophages}

Macrophages obtained by peritoneal lavage as described above were seeded $\left(5 \times 10^{6} / \mathrm{ml}\right)$ in RPMI 1640 phenol red free medium supplemented with 10\% FCS in Petri dishes (35 mm diameter) and incubated at $37^{\circ} \mathrm{C}, 5 \% \mathrm{CO}_{2}$ for $4 \mathrm{hrs}$. AVL (0 $10.0 \mu \mathrm{g} / \mathrm{ml}$ ) was added and incubated for an additional 48 hrs. At the end of $48 \mathrm{~h}, 0.5 \mathrm{ml}$ of the supernatant was withdrawn and nitrite accumulation as an indicator of NO production was measured using Griess reagent. ${ }^{[14]}$ Briefly, $0.5 \mathrm{ml}$ of Griess reagent [mixture of $1: 1$ of napthylethylenediamine dihydrochloride $(0.1 \%$ in water) and sulphanilamide $(1 \%$ in $5 \%$ phosphoric acid)] was added to $0.5 \mathrm{ml}$ of supernatant and incubated in the dark at room temperature $\left(25-30^{\circ} \mathrm{C}\right)$ for 10 min. Finally, absorbance at $546 \mathrm{~nm}$ was measured spectrophotometrically and a standard curve using sodium nitrite was used to calculate concentrations of nitrite. To demonstrate specificity, macrophages were incubated in the presence of N-monomethyl arginine [(L-NMMA), $0.1 \mathrm{mM}]$ an established inhibitor of NO production. 


\section{Cytotoxicity assay}

To determine the viability of macrophages in the presence of AVL or DMSO, they were seeded in 96-well tissue culture plates $\left(1 \times 10^{6} \mathrm{cells} / \mathrm{ml}\right.$ of RPMI 1640 , supplemented with $10 \%$ FCS, $0.2 \mathrm{ml}$ per well) and incubated with either AVL $(0-10$ $\mathrm{mg} / \mathrm{ml}$ ) or DMSO (0-1\%) alone for $48 \mathrm{hrs}$. At the end of drug exposure, the MTS assay was performed. ${ }^{[15]}$ Briefly, MTS [\{3(4, 5 dimethylthiazol-2-yl)-5-(carboxymethoxy-phenyl\}-2-(4sulphophenyl)-2H tetrazolium] was prepared (2 $\mathrm{mg} / \mathrm{ml}$ in PBS) and stored in dark at $-20^{\circ} \mathrm{C}$. Another stock solution of phenazine methosulphate (PMS) was prepared $(0.92 \mathrm{mg} / \mathrm{ml}$ in PBS) and stored $-20^{\circ} \mathrm{C}$. Just before use, MTS and PMS were mixed in the ratio of $20: 1$ and $20 \mu \mathrm{l}$ of the solution was added to each well. The plates were then incubated at $37^{\circ} \mathrm{C}$ for $3 \mathrm{hrs}$ and absorbances measured at $490 \mathrm{~nm}$ using a Multiskan ELISA reader (BioRad, USA).

\section{Statistical analysis}

Data were expressed as mean \pm SEM and statistically assessed using one-way ANOVA followed by Tukey test; $\mathrm{P}<0.05$ was considered significant.

\section{Results}

AVL possesses strong acute antiinflammatory activity in carrageenan and dextran-induced animal models of inflammation

AVL at $25 \mathrm{mg} / \mathrm{kg}$, b.w., showed significant antiinflammatory activity in both carrageenan and dextran models. In the control group, paw volume was maximum at the third hour after which the paw volume decreased gradually and therefore readings up to the third hour were recorded (Tables 1 and 2). However, the antiinflammatory activity of AVL was sustained up to the sixth hour (data not shown). Indomethacin served as a positive control and was initially tested at three different concentrations of $2.5,5.0$ and $10.0 \mathrm{mg} / \mathrm{kg}$, b.w. With 2.5 and $5.0 \mathrm{mg} / \mathrm{kg}$, b.w., a maximum of $19.53 \%$ and $21.65 \%$ reduction in paw edema, respectively, was obtained. However, with $10 \mathrm{mg} / \mathrm{kg}$, b.w., a marked reduction of $75 \%$ was obtained and accordingly, this concentration was selected for all experiments.

Chronic antiinflammatory activity of AVL in a complete Freund's adjuvant-induced model of arthritis.

A significant decrease in the primary lesion as evident on day 5 was observed with both AVL $(33.3 \%, \mathrm{P}<0.05)$ and the dexamethasone treated group $(57.69 \%, \mathrm{P}<0.007)$ [Table 3 , Figure 1] as compared to controls. With regard to the secondary lesions, it could only be partially evaluated as no edema formation was evident in the contralateral hind paw of control animals. On the 21st day, a significant decrease in edema volume was observed in the injected paw of both AVL $(52.7 \%$, $\mathrm{P}<0.01)$ and dexamethasone-treated group $(63.51 \%$, $\mathrm{P}<0.005)$.

With regard to the mean arthritic index, the score of AVLtreated animals was not different from that of the control group being 2.0 vs. 1.8 , respectively, indicating that AVL does not possess antiarthritic activity. As expected, the dexamethasonetreated group showed profound antiarthritic activity since it decreased the arthritic index almost 10-fold being 0.17 .

AVL-treated macrophages showed decreased nitric oxide (NO) production

The formation of NO is classically assayed by measuring
Table 1

Effect of Aloe vera (AVL) on carrageenan induced rat paw edema

\begin{tabular}{|c|c|c|c|c|}
\hline \multirow[t]{2}{*}{ Group } & \multirow[t]{2}{*}{$\begin{array}{c}\text { Dose } \\
(\mathrm{mg} / \mathrm{kg}, \text { b.w. })\end{array}$} & \multicolumn{3}{|c|}{$\begin{array}{c}{ }^{a} \text { Edema volume }(m l) \\
(\% \text { inhibition })\end{array}$} \\
\hline & & $1 \mathrm{~h}$ & $2 h$ & $3 h$ \\
\hline Control & - & $0.35 \pm 0.05$ & $0.45 \pm 0.06$ & $0.42 \pm 0.06$ \\
\hline Indomethacin & 10.0 & $\begin{array}{l}0.18 \pm 0.02^{\#} \\
(48.57 \%)\end{array}$ & $\begin{array}{l}0.13 \pm 0.07^{*} \\
(71.11 \%)\end{array}$ & $\begin{array}{r}0.10 \pm 0.02^{*} \\
(76.19 \%)\end{array}$ \\
\hline AVL & 5.0 & $\begin{array}{c}0.36 \pm 0.03 \\
\mathrm{NI}\end{array}$ & $\begin{array}{c}0.51 \pm 0.04 \\
\mathrm{NI}\end{array}$ & $\begin{array}{c}0.41 \pm 0.04 \\
(2.38 \%)\end{array}$ \\
\hline AVL & 25.0 & $\begin{array}{c}0.29 \pm 0.05 \\
(17.14 \%)\end{array}$ & $\begin{array}{c}0.31 \pm 0.02^{@} \\
(31.11 \%)\end{array}$ & $\begin{array}{r}0.16 \pm 0.03^{\$} \\
(61.90 \%)\end{array}$ \\
\hline One-way & $\mathrm{F}$ & 4.460 & 24.374 & 24.948 \\
\hline \multirow[t]{2}{*}{ ANOVA } & $d f$ & 3,20 & 3,20 & 3,20 \\
\hline & $P$ & 0.009 & 0.0001 & 0.0001 \\
\hline
\end{tabular}

aEdema volume and \% inhibition was measured as described in materials and methods and each value is the mean \pm SEM of three experiments, $n=6$ in each group. ${ }^{\circledR} \mathrm{P}<0.05$; ${ }^{\#} \mathrm{P}<0.01 ;{ }^{\$} \mathrm{P}<0.002 ;{ }^{*} \mathrm{P}<0.0002$ as compared to control (Tukey test). NI: No inhibition

Table 2

Effect of Aloe vera (AVL) on dextran induced rat paw edema

\begin{tabular}{lcccc}
\hline Group & $\begin{array}{c}\text { Dose } \\
\text { (mg/kg, b.w.) }\end{array}$ & \multicolumn{3}{c}{$\begin{array}{c}\text { a Edema volume (ml) } \\
\text { (\% inhibition) }\end{array}$} \\
\cline { 3 - 5 } & & $\mathbf{1} \boldsymbol{h}$ & $\mathbf{2} \boldsymbol{h}$ & $\mathbf{3} \boldsymbol{h}$ \\
\hline Control & - & $0.70 \pm 0.04$ & $0.63 \pm 0.06$ & $0.60 \pm 0.05$ \\
Indomethacin & 10.0 & $0.33 \pm 0.09 @$ & $0.21 \pm 0.06^{*}$ & $0.15 \pm 0.06^{* *}$ \\
& & $(52.86 \%)$ & $(66.67 \%)$ & $(75.00 \%)$ \\
AVL & 5.0 & $0.59 \pm 0.04$ & $0.60 \pm 0.03$ & $0.59 \pm 0.04$ \\
& & $(15.71 \%)$ & $(4.76 \%)$ & $(1.67 \%)$ \\
AVL & 25.0 & $0.38 \pm 0.01^{* *}$ & $0.23 \pm 0.03^{*}$ & $0.23 \pm 0.03^{* *}$ \\
& & $(45.71 \%)$ & $(63.49 \%)$ & $(61.67 \%)$ \\
\hline One-way & $\mathrm{F}$ & 8.716 & 21.072 & 23.266 \\
ANOVA & df & 3,20 & 3,20 & 3,20 \\
& $\mathrm{P}$ & 0.001 & 0.0001 & 0.0001 \\
\hline
\end{tabular}

${ }^{a}$ Edema volume and \% inhibition was measured as described in Materials and methods and each value is the mean \pm SEM of three experiments. $n=6$ in each group. $@ \mathrm{P}<0.05$; ${ }^{*} \mathrm{P}<0.005 ;{ }^{*} \mathrm{P}<0.001$ as compared to control (Tukey test). NI: No inhibition

nitrite $\left(\mathrm{NO}_{2}^{-}\right)$production, a primary, stable and nonvolatile breakdown product of NO. The Griess reagent uses sulphanilamide and NED under acidic conditions to yield an azo compound that can be measured spectrophotometrically. AVL caused a $43.64 \%$ decrease in NO production in murine macrophages as compared to control values being $31.0 \mu \mathrm{M}$ vs. $55.0 \mu \mathrm{M}$. The marked decrease in NO production in the presence of L-NMMA $(8.75 \mu \mathrm{M})$ confirmed specificity of the reaction.

\section{Toxicity of AVL in macrophages}

As AVL decreased NO production in macrophages, it was relevant to confirm that this decrease was not due to AVL or DMSO induced cell death but specifically by macrophage 
Table 3

Chronic antiinflammatory activity of Aloe vera (AVL) in an adjuvant arthritis model

\begin{tabular}{|c|c|c|c|c|c|c|}
\hline \multirow[t]{2}{*}{ Group } & \multirow{2}{*}{$\begin{array}{c}\text { Dose } \\
\text { (mg/kg, b.w.) }\end{array}$} & \multicolumn{5}{|c|}{${ }^{a}$ Edema volume $(\mathrm{ml})(\%$ inhibition) } \\
\hline & & Day 3 & Day 5 & Day 9 & Day 13 & Day 21 \\
\hline Control & - & $0.7 \pm 0.07$ & $0.78 \pm 0.1$ & $0.51 \pm 0.05$ & $0.55 \pm 0.08$ & $0.74 \pm 0.13$ \\
\hline AVL & 25 & $\begin{array}{c}0.58 \pm 0.02 \\
(17.14 \%)\end{array}$ & $\begin{array}{l}0.52 \pm 0.05^{*} \\
(33.33 \%)\end{array}$ & $\begin{array}{c}0.48 \pm 0.04 \\
(5.88 \%)\end{array}$ & $\begin{array}{c}0.39 \pm 0.03 \\
(29.09 \%)\end{array}$ & $\begin{array}{c}0.35 \pm 0.07^{* *} \\
(52.7 \%)\end{array}$ \\
\hline Dexamethasone & 0.1 & $\begin{array}{c}0.33 \pm 0.02^{* *} \\
(52.86 \%)\end{array}$ & $\begin{array}{c}0.33 \pm 0.02^{* *} \\
(57.69 \%)\end{array}$ & $\begin{array}{c}0.22 \pm 0.06^{\star *} \\
(56.86 \%)\end{array}$ & $\begin{array}{c}0.18 \pm 0.08^{* *} \\
(67.27 \%)\end{array}$ & $\begin{array}{c}0.27 \pm 0.03^{* * *} \\
(63.51 \%)\end{array}$ \\
\hline One-way & $\mathrm{F}$ & 20.11 & 12.55 & 9.175 & 7.950 & 3.565 \\
\hline ANOVA & $\mathrm{df}$ & 2,15 & 2,15 & 2,15 & 2,15 & 2,15 \\
\hline & $P$ & 0.0001 & 0.01 & 0.002 & 0.004 & 0.056 \\
\hline
\end{tabular}

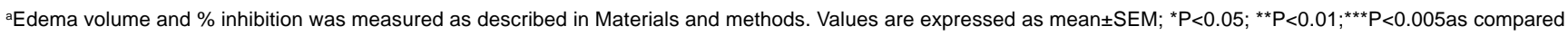
to control (Tukey test). $\mathrm{n}=6$ in each group.

Figure 1. Effect of Aloe vera (AVL) in an adjuvant arthritis model in rats.

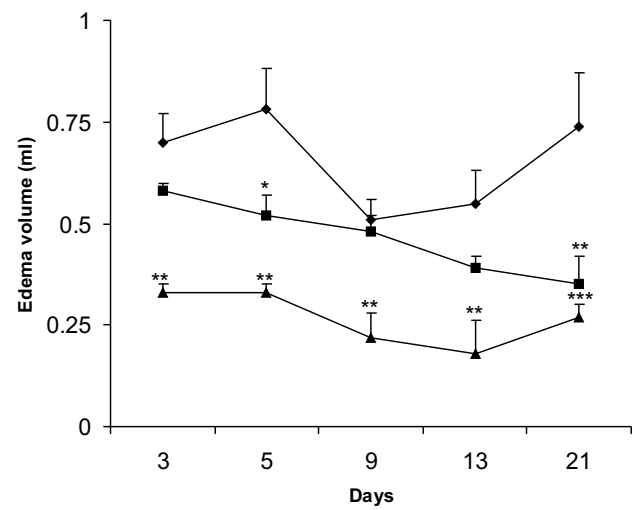

Arthritis was established using complete Freund's adjuvant and the animals received no drug (- -), AVL (-ם-, $25 \mathrm{mg} / \mathrm{kg} \mathrm{b.w.)} \mathrm{or}$ dexamethasone (-А-, $0.1 \mathrm{mg} / \mathrm{kg}$ b.w.). The degree of inhibition of edema formation was measured plethysmographically on days 3,5 , 9,13 and 21 . Each point is the mean \pm SEM of two experiments $(n=6$ in each group), ${ }^{*} \mathrm{P}<0.05 ;{ }^{* *} \mathrm{P}<0.01 ;{ }^{* *} \mathrm{P}<0.005$ as compared to control (one-way ANOVA followed by Tukey test).

inactivation. Accordingly, macrophages were incubated with AVL or DMSO and cell viability was determined by the MTS assay. Since this conversion can only be accomplished by viable cells, the amount of formazan is a direct measure of the number of cells present. ${ }^{.14]}$ It was found that DMSO up to 0.5\% was nontoxic to macrophages (Figure $2 \mathrm{~A}, \mathrm{p}=0.72$ ). However, with $1.0 \%$ DMSO, a significant increase in toxicity was observed (Figure 2A, $\mathrm{P}<0.0001$ ). AVL up to a concentration of $0.1 \mathrm{mg} /$ $\mathrm{ml}$ showed no decrease in viability (Figure $2 \mathrm{~B}, \mathrm{P}=0.31$ ) but with higher concentrations $(>0.25 \mathrm{mg} / \mathrm{ml})$, a significant decrease in viability was observed (Figure 2B, $\mathrm{P}<0.0001$ ). Accordingly, all experiments were performed using a maximum of $0.1 \%$ DMSO or $0.1 \mathrm{mg} / \mathrm{ml} \mathrm{AVL}$.

\section{Discussion}

The inhibition of carrageenan-induced inflammation in rats is an established model to screen compounds for potential
Figure 2. Effect of DMSO and Aloe vera (AVL) on viability of murine peritoneal macrophages.

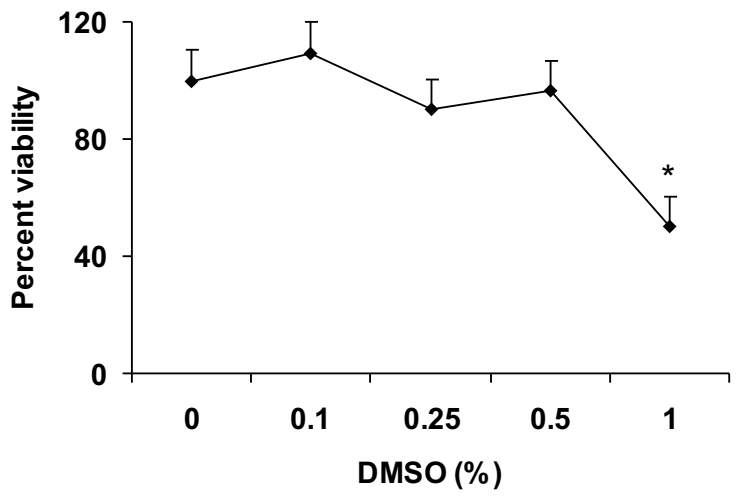

A: Macrophages were incubated with DMSO (0 - 1\%) in 96 well plates at $37^{\circ} \mathrm{C}$ and $5 \% \mathrm{CO}_{2}$ for $48 \mathrm{~h}$. Each point is the mean \pm SEM of three experiments in duplicates, ${ }^{*} \mathrm{P}<0.0001$ as compared to control (oneway ANOVA followed by Tukey test).

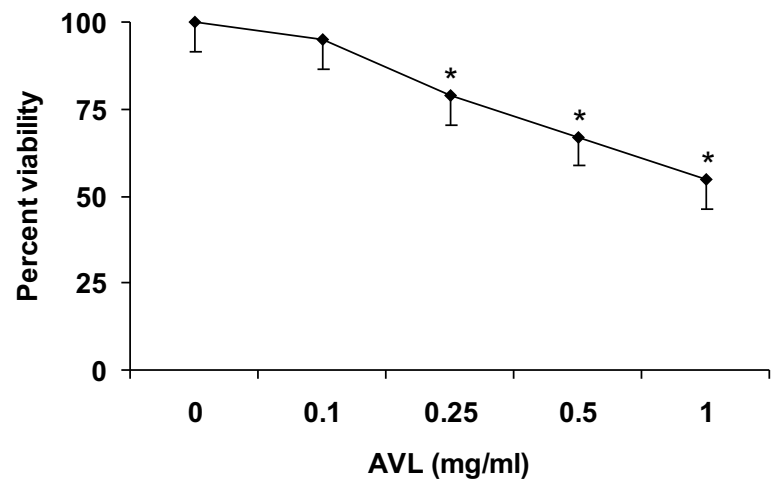

B: Macrophages were seeded in 96 well plate with AVL $(0-1 \mathrm{mg} / \mathrm{ml})$ for $48 \mathrm{~h}$ at $37^{\circ} \mathrm{C}$ and $5 \% \mathrm{CO}_{2}$. Each point is the mean \pm SEM of three experiments in duplicates, ${ }^{*} \mathrm{P}<0.0001$ as compared to control (oneway ANOVA followed by Tukey test). 
antiinflammatory activity. According to Vinegar et al. (1987), ${ }^{[16]}$ the development of carrageenan-induced edema is biphasic; the first phase occurs within one hour of carrageenan administration and is attributed to the release of cytoplasmic enzymes, histamine and serotonin, from the mast cells. The second phase $(>1.0 \mathrm{~h})$ is mediated by an increased release of prostaglandins in the inflammatory area and continuity between the two phases is provided by kinins. With regard to dextran-induced edema, it has been reported to be mediated mainly by histamine and 5-HT released by the mast cells. ${ }^{[17]}$ Taken together, it suggests that as AVL possesses potent acute antiinflammatory activity (Tables 1 and 2), it is mediated possibly due to inhibition of the synthesis and/or release of mediators of inflammation, principally the prostaglandins. This can only be defined after developing models of inflammation using specific mediators.

The immunologically mediated complete Freund's adjuvant arthritic model of chronic inflammation is considered as the best available experimental model of rheumatoid arthritis. ${ }^{[18]}$ This method in rats was originally developed by Pearson et al. (1963), ${ }^{[19]}$ wherein an injection of complete Freund's adjuvant in the rat hind paw induces inflammation. It has been proposed that bacterial peptidoglycan and muramyl dipeptide are important nonspecific immunogenic contributory components. In this model of immunologically mediated chronic synovial inflammation and arthritis, macrophages play a central role. After activation they are capable of synthesizing mediators such as $\mathrm{PGE}_{2}$ and cytokines such as TNF- $\alpha$ and IL-1. In turn, these synthetic products induce the production of a variety of enzymes which initiate cartilage and bone destruction. ${ }^{200, \text { [21] }}$

NO is an important physiological messenger and effector molecule in many biological systems, including immunological, neuronal and cardiovascular tissues. ${ }^{[22]}$ Nitric oxide, in macrophages, is produced as a free radical by iNOS by catalyzing the oxidation of guanidino nitrogen of L-arginine, thereby converting L- arginine to L-citrulline. ${ }^{[22]} \mathrm{NO}$ is an important signalling and effector molecule in inflammation and immunity as it is known to couple with superoxides to form peroxynitrite. These, in turn, induce the production of prostaglandin endoperoxide synthase from monocytes/ macrophages resulting in enhanced synthesis of prostaglandins, established mediators of inflammation. ${ }^{[23]}$ The reduced NO production by macrophages in the presence of AVL suggests that AVL by decreasing the release of NO, inhibits the release of inflammatory inhibitors such as prostaglandins resulting in suppression of inflammation. This can be confirmed by measuring the expression of iNOS in macrophages; such studies are ongoing.

\section{Acknowledgements}

The work received financial support from the Council of Scientific and Industrial Research, Govt. of India and the University Grants Commission, New Delhi. DS was a recipient of a Junior Scholarship from the Lady Tata Trust. We express our sincere thanks to Sri Ramphal Mullick for his excellent technical assistance.

\section{References}

1. Gryglewski RJ. Molecular mechanisms of inflammation. Eur J Rheumatol Inflamm 1981;4: 153-9.

2. Freeman BD, Natanson $C$. Antiinflammatory therapies in sepsis and septic shock. Expert Opin Investigl Drugs 2000;9:1651-63.

3. Saccu D, Bogoni P, Procida G. Aloe Exudate: Characterization by reverse phase HPLC and Headspace GC-MS. J Agric Food Chem 2001;49:4526-30.

4. Atherton P. Aloe vera: Magic or medicine? Nurs Stand 1998;41:49-54.

5. Reynolds T, Dweck AC. Aloe vera leaf gel: A review update. J Ethnopharmacol 1999;68:3-37.

6. Bautista-Perez R, Segura-Cobos D, Vasquez-Cruz B. In vitro antibradykinin activity of Aloe barbadensis gel. J Ethnopharmacol 2004;93:89-92.

7. Langmead L, Makins RJ, Rampton DS. Anti-inflammatory effects of Aloe vera gel in human colorectal mucosa in vitro. Aliment Pharmacol Ther 2004;19:521-7.

8. Winter CA, Rislay EA, Nuss GW. Carrageenin induced edema in hind paw of the rats as an assay for anti inflammatory drugs. Proc Soc Exp Biol Med 1962;111:544-7.

9. Rowley DA, Benditt EP. 5-hydroxytryptamine as mediators of vascular injury provided by agents which damage mast cells in rats. J Exp Med 1956;130:399415.

10. Tsai CC, Lin CC. Anti-inflammatory effects of Taiwan folk medicine 'Teng-Khia$U$ ' on carrageenan- and adjuvant-induced paw edema in rats. J Ethnopharmacol 1999;64:85-9.

11. Newbould BB. Chemotherapy of arthritis induced in rats by mycobacterial adjuvant. Br J Pharmacol 1963;21:127-36.

12. Schorlemmer HU, Kurrle R, Schleyerbach R, Bartlett RR. Disease modifying activity of malononinitrilamides, derivates of leflunomide's active metabolite, on models of rheumatoid arthritis. Inflammation Research 1999;48:113-4.

13. Hudson L, Hay FC. Practical Immunology. $3^{\text {rd }}$ ed. Oxford, London: Blackwell Scientific Publications; 1989.

14. Hibbs JB Jr., Taintor RR, Vavrin Z, Rachlin EM. Nitric oxide: A cytotoxic activated macrophage effector molecule. Biochem Biophys Res Commun 1988:157:87-94.

15. Barltrop JA, Owen TC, Cory AH, Cory JG. 5-(3-carboxymethoxyphenyl)-2-(4,5dimethylthiazolyl)-3-(4-sulfophenyl) tetrazolium, inner salt (MTS) and related analogs of 3-(4,5-dimethylthiazolyl)-2,5-diphenyltetrazolium bromide (MTT) reducing to purple water soluble formazans as cell-viability indicators. Bioorg Med Chem Lett 1991;1:611-4.

16. Vinegar R, Truax JF, Selph JH, Johnston PR, Venable AL, McKenzie KK. Pathway to carrageenan-induced inflammation in the hind limb of the rat. Fed Proc 1987;46:118-26.

17. Lo TN, Almeida AP, Beaven MA. Dextran and carrageenan evoke different inflammatory responses in rat with respect to composition of infiltrates and effect of indomethacin. J Pharmacol Exp Ther 1982;221:261-7.

18. Williams RO. Rodent models of arthritis: relevance for human disease. Clin Exp Immunol 1998;114:330-2.

19. Pearson CM, Wood FD. Studies of arthritis and other lesions induced in rats by the injection of mycobacterial adjuvant. VII. Pathological details of the arthritis and spondylitis. Am J Pathol 1963;42:73-95.

20. Hopkins SJ. Cytokines and eicasonoids in rheumatic diseases. Ann Rheum Dis 1990;49:207-10.

21. Jadot G, Michelson AM, Puget K. Anti-inflammatory activity of superoxide dismutases; Studies on adjuvant induced polyarthritis in rats. Free Radic Res Commun 1986;2:27-42.

22. MacMicking J, Xie $Q$, Nathan $C$. Nitric oxide and macrophage function. Annu Rev Immunol 1997;15:323-50.

23. Landino LM, Crews BC, Timmons MD, Morrow JD, Marnett LJ. Peroxynitrite, the coupling product of nitric oxide and superoxide, activates prostaglandin biosynthesis. Proc Natl Acad Sci USA 1996;93:15069-74. 